\title{
ENHANCE MOTHER BEHAVIOR ON IMPROVEMENT STAUTS NUTRITION BABY OF FIVE YEARS
}

\author{
Yolanda Harianja ${ }^{1}$ \\ ${ }^{1}$ Post Graduate Student Public Health, Faculty Public Health Universitas Prima Indonesia, North \\ Sumatera Indonesia \\ Chrismis Novalinda Ginting ${ }^{2}$, Sri Wahyuni Nasution ${ }^{3}$, Ermi Girsang ${ }^{4}$ \\ ${ }^{2,3,4}$ Lecture Of Magister Public Health, Faculty Public Health Universitas Prima Indonesia, North \\ Sumatera, Indonesia.
}

\begin{abstract}
Baby growth monitoring through weighing carried out every month shows the percentage of infants aged 6-59 months who have never weighed in the past six months tended to increase. in the study contains the relationship between inner behavior weighing toddlers with nutritional status of children in the working area of Talun Health Center Kenas Sub-District of Lower STM in 2018 which is of a nature analytic with cross sectional approach. The population in this study was all baby aged 6-59 months as many as 1,082 baby scattered in 13 Posyandu. Sample in this study 92 toddlers, taking samples by purposive sampling using proportional random sampling method. so the results of the research can be a reference to the Health Office more improve health services at the posyandu level intensively especially on improving nutrition such as supplementary feeding programs and provide information on the importance of weighing toddlers and providing facilities which supports activities. Keywords: Nutritional Status, Mother's Behavior, Weighing Toddlers
\end{abstract} Keywords: Monitorting Baby Growth, Nutrition Status, mother behavior

\section{INTODUCTION.}

The process of child development during the critical period of the first 3 years of life must be monitored and recorded properly, which aims to find the existence of disorders of early growth so that treatment can be done as early as possible before the child passes the critical period (Ranuh, 2014).From the data from the 2013 Basic Health Research (Riskesdas), there were 19.6\% of malnourished children consisting of $5.7 \%$ of children under five with malnutrition and $13.9 \%$ of those with malnutrition and information on monitoring child growth obtained from the frequency of weighing children under five for the past six months, ideally toddlers should be weighed at least six times.

Other studies related to early detection of child growth irregularities have been carried out by Chesney, Chesney has conducted research on the causes of impaired growth and development of children due to several factors including: lack of attention from parents, incomplete immunization at an early age, food poisoning (Chesney, 2013).

One of the factors that led to a decrease in under-five growth monitoring in the Puskemas was due to the mother's ignorance of the benefits of weighing her child in the Puskemas (BKKBN in the Indonesian Ministry of Health, 2013).

Awareness of parents to check their toddler children regularly in the Public Health Center is 
still relatively low. In fact, routine examinations such as weighing and measuring the height of children in the Puskemas are very necessary to monitor the child's growth period. Growth disorders (growth faltering) can also be detected and overcome early. Parents tend to feel that there is no need to weigh and check their child in the health center after the child is immunized at the age of three. In addition, several other reasons such as feeling lazy or busy because work is also a barrier for mothers to routinely come to the Puskemas. The role of parents is needed to improve the growth and development of children, especially at the age of zero to six years (Jurnal Buana Informatika, 2016).

Preliminary survey results conducted in the work area of Aek Habil Health Center in Sibolga City (2015), Aek Habil Health Center in charge of 2 Villages namely Aek Habil Village and Aek Manis Village where 45 children (2.88\%) have weighing below the red line or can be called BGM, $15 \%$ experience malnutrition and $0.19 \%$ malnutrition. Toddler mothers come to bring their children to the posyandu if there is an additional feeding program. Related to this, the influence of the problems that exist if every toddler is not considered monitoring of growth and development will have an impact on nutritional problems.

\section{LITERATURE REVIEW.}

\subsection{Direct Assessment of Nutritional Status}

Anthropometry comes from anthropos and metros anthropos means body and metros means size. In general anthropometry is a measure of the human body viewed from the point of view of nutrition and anthropometry nutrition related to various age levels and nutrient levels. Anthropometry is used to measure nutritional status from various imbalances between energy and protein intake which can be seen from physical growth patterns and the proportion of growth tissue such as fat, muscle and body water amount (Supariasa, 2017).

Anthropometry as an indicator of nutritional status can be done by measuring several parameters. Parameters are the single size of the human body, among others: age, weight, height, upper arm circumference, head circumference, chest circumference, hip circumference and fat under the skin (Indrianti, 2015). Some anthropometric indices are often used as a basis for evaluating nutritional status, namely:

a. Body Weight by Age (BB / U)

Body weight is one parameter that gives a very labile picture of body mass and anthropometry, based on these characteristics, the body weight index according to age is used as one way to measure a person's nutritional status at that time, under normal circumstances, body weight develops following age.

b. Body Height by Age (TB / U)

Height is an anthropometry that describes the state of growth. Growth of height not like weight is relatively less sensitive to the problem of malnutrition in a short time so this index describes the nutritional status of the past. In normal circumstances, height grows with age.

c. Body Weight (Height / Weight)

Body weight has a linear relationship with height in normal circumstances, the development of 
body weight will be in line with the growth of height at a certain speed. Of the various types of indices, a threshold is needed to interpret it, the determination of the threshold is needed in agreement with nutritionists. Threshold can be presented into the unit standard deviation.

\subsection{Indirect Assessment of Nutritional Status}

Method by looking at the amount and type of food consumed, to provide an overview of consumption of various nutrients in the family and individual communities. such as mortality based on age, morbidity and mortality due to certain causes and other data related to nutrition. Measurement of ecological factors is seen as very important to determine the causes of malnutrition in a community as a basis for conducting an intervention program (Supariasa, 2017).

Behavior is something that is done by the organism, both can be observed directly or indirectly. This means that new behavior occurs when something is needed to cause a reaction, which is called stimulation. Thus, stimulation of a particular stimulus will produce a certain reaction or behavior (Notoatmodjo, 2014).

There are two views related to the definition of behavior itself which can be seen from a biological and psychological point of view. In terms of biology the definition of behavior is an activity or activity of the organism (living thing) concerned. From the biological point of view of all living things from plants, animals, and humans behave because of their respective activities. Human behavior is all human actions or activities that can be observed directly and which are not observed by outsiders. The development of psychology as a basis for behavioral science has undergone some fundamental changes or can be said to be a revolution, namely the emergence of behavioral psychology streams namely the Predisposing, Enabiling, Reinforcing factors.

\section{METHOD OF RESEARCH.}

The location in this study was conducted in the Talun Kenas Community Health Center Working Area in STM Hilir District. The reason for choosing this location is because the participation of underfive weighing is still low and the nutritional status of children under five is lacking, and mothers come to bring their children to the posyandu if there is only extra food.

Sampling in this study was conducted by means of purposive sampling where the subject was taken based on the existence of certain objectives with several considerations, namely:

1. Toddlers who have KMS

2. Toddlers whose homes are affordable for researchers

3. Respondents know reading and writing

Respondents in this study were mothers who had toddlers aged 6-59 months in the working area of Talun Kenas Health Center, STM Hilir Subdistrict in 2018.

The sampling method is carried out in a simple random manner according to the criteria based on the proportion of each sample in each posyandu.

Data analysis in this study uses the following techniques:

1. Univariate Analysis

Done to describe each variable, namely the independent variable (mother's behavior in weighing 
the toddler) and the dependent variable (under-fives nutrition status). This analysis is in the form of frequency distribution and percentage of each variable.

2. Bivariate Analysis

This analysis is used to determine the relationship between independent variables and dependent variables in order to determine the level of the relationship between these variables. In this study used statistical tests with the Chi-Square test with the help of SPSS for Windows. The Chi-Square test is used because the variable measurement scale in this study is a categorical measurement scale and includes non-parametric tests.

\section{ANALYZE AND RESULT.}

Age of respondents divided into three groups, namely age 21-30 years and age 31-40 years and age $>40$ years. This is in accordance with the standards of the Indonesian Ministry of Health in 2009 , the division of age can be divided based on the level of maturity, where between the ages of young adults with older adults around the age of 30 years This can be seen in the table below

Table 4.1 Frequency Distribution of Respondents by Age at Talun Kenas Health Center, STM

Hilir Subdistrict in 2018

\begin{tabular}{lrll}
\hline Age of Respondents & Amount & \\
\cline { 2 - 4 } & $\mathrm{N}$ & $\%$ \\
\hline $21-30$ Tahun & 44 & 47.8 \\
$31-40$ Tahun & 33 & 35.9 \\
$>40$ & 15 & 16.3 \\
\hline \multicolumn{1}{c}{ Total } & $\mathbf{9 2}$ & $\mathbf{1 0 0 . 0}$ \\
\hline
\end{tabular}

Based on table 4.1 shows that from 92 respondents the majority of respondents are aged 21 30 years A total of 44 people (47.8\%) and age> 40 as many as 15 people (16.3\%). The data shows that the majority of respondents are adults where in acting and making decisions, age factors become one of the influences. Increasingly increasing age psychologically, the maturity of someone in acting is getting better. Every human resource owned can be optimized and developed related to efforts specifically to improve the nutritional status of children in the Talun Kenas Community Health Center, STM Hilir Subdistrict. Social status is the concept of all human endeavors to fulfill the need to achieve life's prosperity and which concerning society can be measured by work and the use of finance to achieve optimal health status. 
Tables 4.2 Frequency Distribution of Respondents by Job at Talun Kenas Health Center, STM Hilir Subdistrict in 2018

\begin{tabular}{lcc}
\hline Job & \multicolumn{2}{c}{ Amount } \\
\cline { 2 - 3 } & $\mathrm{n}$ & $\%$ \\
\hline Work & 25 & 27.2 \\
Unwork & 67 & 72.8 \\
\hline Total & 92 & 100.0 \\
\hline
\end{tabular}

Based on table 4.2 shows the majority of respondents did not work or only a housewife as many as 67 people $(72.8 \%)$.

Mother's education is an important factor that influences mother's knowledge and attitudes towards healthy living behaviors and the ability to cope with problems faced daily including health problems.

Table 4.3 Frequency Distribution of Respondents by Education at the Talun Kenas Community Health Center, Lower STM Subdistrict in 2018

\begin{tabular}{llc}
\hline Educations & \multicolumn{2}{c}{ Amount } \\
\cline { 2 - 3 } & $\mathrm{N}$ & $\%$ \\
\hline SLTP & 39 & 42.4 \\
SMA & 53 & 57.6 \\
\hline Total & 92 & 100.0 \\
\hline
\end{tabular}

Based on table 4.3 shows the majority of respondents with high school education as many as 53 people $(57.6 \%)$ and junior high school as many as 439 people $(2.4 \%)$. The higher the level of education of a mother it will be easy for the mother to obtain information about health.

The age of the toddler is divided into 2 groups, namely 12-23 months and 24-59 months.

Table 4.4 Frequency Distribution Based on Age of Toddlers in Talun Kenas Health Center, Lower STM District, 2018

\begin{tabular}{llc}
\hline Ages Baby & \multicolumn{2}{c}{ Amount } \\
\cline { 2 - 3 } & $\mathrm{N}$ & $\%$ \\
\hline 12-23Months & 17 & 18.5 \\
24-59Months & 75 & 81.5 \\
\hline Total & 92 & 100.0 \\
\hline
\end{tabular}

Based on table 4.4 shows that the majority of the sample age was $24-59$ months of age as many as 75 children (81.5\%).Determination of nutritional status on the results of anthropometric measurements of body weight, height using standard values (Z-Score). The results of this study can be seen in the following table: 
Table 4.5. Frequency Distribution of Nutritional Status based on BB / U at Talun Kenas Health Center, Lower STM District, 2018

\begin{tabular}{lcl}
\hline Nutritional status & \multicolumn{2}{c}{ Amount } \\
\cline { 2 - 3 } & $\mathrm{n}$ & $\%$ \\
\hline Malnutrition & 3 & 3.3 \\
Malnutrition & 17 & 18.5 \\
Normal Nutrition & 71 & 77.2 \\
More nutrition & 1 & 1.1 \\
\hline Total & 92 & 100.0 \\
\hline
\end{tabular}

Based on table 4.5 shows that the majority of toddlers are in normal nutrition, namely 71 toddlers (77.2), 17 toddlers $(18.5 \%)$ experience malnutrition and 1 toddler $(1.1 \%)$ experience over nutrition and still find 3 toddlers $(3.3 \%)$ experiencing malnutrition.

\section{CONCLUSIONS.}

Based on the results of the study it can be concluded that:

1. The results of the univariate analysis resulted in the majority of children under five having good nutritional status, but still found the nutritional status of children under five was $18.5 \%$ and $3.3 \%$ experienced poor nutrition.

2. There is a relationship between the knowledge of mothers in weighing children under five with nutritional status of children under the age of BB / U and TB / TB in the working area of Talun Kenas Community Health Center, STM Hilir Subdistrict in 2018.

3. There is a relationship between the attitudes of mothers in weighing toddlers with nutritional status of children under the age of BB / U, TB / U in the working area of Talun Kenas Health Center, STM Hilir Subdistrict in 2018.

4. There is a relationship between the actions of mothers in weighing toddlers with nutritional status of children under the age of BB / U, TB / U and BB / TB in the working area of Talun Kenas Health Center, STM Hilir Subdistrict in 2018.

\section{REFERENCES.}

Adriani, M. dan Wirjatmadi, B. (2014). Gizi Dan Kesehatan Balita. Jakarta:Kencana Prenadamedia GroupArisman, 2007.Gizi Dalam DaurKehidupan, Jakarta: EGC

Arikunto, 2013. Prosedur Penelitian Suatu Pendekatan Praktik. Jakarta: RinekaCipta

Chesney, Russell W. 2013. The Disappearance of Diseases, Conditions, andDisorders of Childhood. The Journal of Pediatrics, 162(5) : 903-905.

Departemen Gizi dan Kesehatan Masyarakat FKUI, 2015, Keluarga MandiriSadar Gizi, Jakarta.

Devi, M. 2016. Analisis Faktor-Faktor yang Berpengaruh terhadap Status giziBalita di Pedesaan. Jurnal Teknologi dan Kejuruan, Vol.33, No.2:183-192.

Hasan, Nur Ain Olivia. 2013. Faktor -faktor Yang Berhubungan denganPartisipasi Ibu Balita 
dalam Kegiatan Posyandu Di KelurahanKayumerah Kecamatan Limboto Kabupaten Gorontalo. Skripsi.Universitas Negeri Gorontalo

Hendriani ; Farida, 2016. Hubungan pendidikan, pekerjaan, pengetahuan dankepuasan ibu terhadap posyandu dengan frekuensi kunjungan balitake posyandu di puskesmas. Fakultas Kedokteran UniversitasLampung Mangkurat.

Hidayat.A.A.2017.Metode Penelitian Keperawatan dan Teknik Analisa Data.Jakarta. Salemba Medika.

Hindu, S.M.; Santosa, H.; Firia.M. 2013. Faktor-Faktor yang BerhubunganDengan Tingkat Partisipasi Ibu dalam Penimbangan Balita kePosyandu di Wilayah Kerja Puskesmas Darussalam KecamatanMedan Petisah Tahun 2013. Jurnal Gizi,Kesehatan Reproduksi danEpidemiologi, Vol 2,No.6 (2013) : 8-9.

Indriyani,S. 2013, Gizi Buruk dan pola asuh anak.

Indriati, E. (2015). Antropometri untuk kedokteran, keperawatan, gizi danolahraga. Yogyakarta: PT.Citra Aji Parama.

Ismawati, C. S.; Proverawati, A., dan Pebriyanti, S. 2015. Posyandu dan DesaSiaga.Yogyakarta : Nuha Medika.

Jannah,; Musrifatul. 2015. Pengaruh tingkat pendidikan pengetahuan jaraktempat tinggal dan sikap ibu kepada pelayanan petugas puskesmasterhadap frekuensi kunjungan ibu ke posyandu di kabupatenLamongan. Universitas Negeri Surabaya.

Julita Nainggolan,; Zuraida,R. 2017. Hubungan antara Pengetahuan dan SikapGizi Ibu dengan Status Gizi Balita di Wilayah Kerja PuskesmasRajabasa Indah Kelurahan Rajabasa Raya Bandar Lampung. Medical

Journal Of Lampung University.Vol 1.No.1.2012.

Jurnal Buana Informatika, Volume 7, Nomor 1, Januari 2016: 65-74Kartini, A,; Asdhany,C. 2015. Hubungan Tingkat Partisipasi Ibu dalamKegiatan Posyandu dengan Status Gizi Anak Balita (Studi diKelurahan Cangkiran Kecamatan Mijen Kota semarang). Journal OfNutrition College,I(1). 